\title{
Rapid assessment of butterfly diversity of two proposed Community Resource Management Areas (CREMAs) in the Western North Region of Ghana: Implication for conservation
}

\author{
CHRISTIANA NAA DEEDEI TETTEY ${ }^{1}$, ROGER SIGISMUND ANDERSON ${ }^{2, \bullet}$, ROSINA KYEREMATEN $^{1, \bullet \bullet}$ \\ ${ }^{1}$ Department of Animal Biology and Conservation Science, University of Ghana. P. O. Box LG 67, Legon, Ghana. `email: rkyerematen@ug.edu.gh; \\ naadeedei84@gmail.com \\ ${ }^{2}$ African Regional Postgraduate Program in Insect Science, University of Ghana. P. O. Box LG59, Legon, Ghana. • ${ }^{*}$ email: sigiandy@ hotmail.com
}

Manuscript received: 4 March 2020. Revision accepted: 23 July 2020.

\begin{abstract}
Tettey CND, Anderson RS, Kyerematen R. 2020. Rapid assessment of butterfly diversity of two proposed Community Resource Management Areas (CREMAs) in the Western North Region of Ghana: Implication for conservation. Biodiversitas 21: $3699-3706$. Community Resource Management Areas (CREMAs) are non-reserved land masses with local communities living in them that contain important components of biodiversity and are open to free access. Biodiversity in these off-reserve areas in Ghana is fast depleting due to unsustainable anthropogenic activities. The Rapid Biodiversity Assessment (RBA) method was conducted in the proposed Manzan and Yawmatwa CREMAs in Sefwi-Debiso; in the Western North Region of Ghana using butterflies as indicator taxa to estimate species richness and diversity in two proposed CREMAs to prioritize these rapidly diminishing forest areas for conservation. A total of 1,352 individual butterflies were recorded at the end of a two-week rapid assessment; with 83 species belonging to five families (Nymphalidae, Papilionidae, Pieridae, Lycaenidae, and Hesperiidae). The findings of the study revealed that $38.5 \%$ of the butterfly population belongs to species associated with severe forest disturbance; indicating that these ecosystems are gradually being threatened by ongoing anthropogenic activities. Management efforts aimed at butterfly conservation should be geared towards protecting these proposed CREMAs from excessive human disturbances.
\end{abstract}

Keywords: Anthropogenic, butterflies, conservation, CREMA, diversity, RBA

\section{INTRODUCTION}

The Community Resource Management Areas (CREMAs) mechanism is innovative natural resource governance and landscape-level planning tool that authorizes communities to manage their own natural resources for economic livelihood benefits (Hinneh 2017). In Ghana, there are two types of areas when it comes to wildlife conservation: the reserved areas and the offreserved areas. The reserved areas are usually protected by governmental laws and policies. These include the national parks, forest reserves, Ramsar sites, resource reserves, game reserves, and others. Off-reserve areas are the portions of non-reserved land masses owned by the local people, open to free access, containing important components of biodiversity. These areas include wetlands, farmlands, water bodies, urban forests and CREMAs. These off-reserve areas are constantly under threat of depletion of biological resources and call for conservation interventions, mainly because they are rich in biodiversity and open to free access. The health of these off-reserves therefore, need to be assessed to determine their current ecological status; and prioritized for conservation. One of the major barriers to effective planning and implementation of conservation actions in highly diverse tropical ecosystems, particularly in remote areas, is lack of data. Rapid Biodiversity Assessment (RBA) is considered to be a good tool to predict species richness utilizing indicator taxa
(Pearson and Cassola 1992). The relevance of these RBAs is that they only use a taxonomic group as an indicator of the site. Over the years, butterflies have been used to assess the health of pristine and anthropogenic ecosystems, and have been beneficially exploited to study numerous aspects of tropical forest ecology in natural, managed and degraded ecosystems (Kyerematen et al. 2014, 2018). Butterfly species are found in different types of habitats, depending on the ecology of the ecosystems. These include deep forests, open habitat or degraded forests, savannah, guinea savannah, and transitional zones (Bakowski and DokuMarfo 2009). The abundance and diversity of butterfly species in a particular ecosystem is an indication of the health of that environment because member species exhibit a diversity of relative sensitivities to environmental change (Kyerematen et al. 2014). A strong understanding of insect responses to human activity is, therefore, necessary both to support policy decisions for conservation and to evaluate the consequences of human disturbance on ecosystems.

A rapid survey of butterflies in Ajenjua Bepo and Mamang River Forest Reserves in the Eastern Region of Ghana conducted by Bakowski and Doku-Marfo in 2009 concluded that less disturbed forest coverage has a better candidate for any conservation activity. A study by Nganso et al. (2012), on butterfly diversity in the Abiriw and Odumante sacred grooves found that such communityowned forests hold a rich source of biodiversity. Orimaye et al. (2016), also conducted a similar survey comparing 
butterflies in some protected and unprotected areas in Nigeria. The findings indicated that mature secondary and regenerated forests supported high butterfly diversity and species richness; and therefore, these unprotected areas which hold a rich source of biodiversity warrant conservation interventions.

The Western North Region has many unsullied forest ecosystems including the Bia National Park and other protected areas that are rich in biodiversity. The proposed Manzan and Yawmatwa CREMAs are about $10 \mathrm{~km}$ to the North of the Bia National Park, now a Biosphere Reserve (the only one in the country according to the Forestry Commission of Ghana), which has one of Ghana's last remnants of unmanaged forests with high diversity of wildlife (Forestry Commission of Ghana 2010). The proposed CREMAs may host high numbers of species from the Bia Conservation Area and may serve as secondary habitats or migration sites to many species outside the main Biosphere reserve. This may be as a safeguard in cases of poaching, and other forest disturbances, which may cause habitat destruction, leading to displacement of biodiversity. Many of Ghana's CREMAs may be home to many species, some yet to be described by science and there is a high risk of losing this vast biodiversity and resource if they are not well managed. Rapid Biodiversity Assessment (RBA) is thus necessary to explore and document insect diversity, which represents a major proportion of the faunal diversity of tropical forests (Zakaria et al. 2016); enabling stakeholders to make a decision on whether these two proposed CREMAs warrant any conservation intervention. This study will create awareness for countries across the globe to pay attention to their off-reserve areas that may contain rich sources of biodiversity, and put in proper conservation measures to protect these them. Such portions of non-reserve land masses could serve as supplementary biodiversity areas to replace some of the fast depleting forest biodiversity thereby enhancing in situ biodiversity conservation globally.

\section{MATERIALS AND METHODS}

\section{Study area}

The Manzan and Yawmatwa CREMAs are located in the Bia West District in the Western North Region of Ghana $\left(6.6637^{\circ} \mathrm{N}, 3.0932^{\circ} \mathrm{W}\right)$, and about $10 \mathrm{~km}$ to the North of the Bia National Park. The district forms part of the semi-equatorial climatic zone, and has an average annual rainfall ranging from $1,250 \mathrm{~mm}$ to $2,000 \mathrm{~mm}$. The combined area of both CREMAs is about $27,825.77 \mathrm{Ha}$. The Manzan CREMA located near the Ghana - Cote de Ivoire border in Oseikojokrom, is farmland primarily dominated by cocoa and plantain. Most of the land in the Manzan CREMA is cultivated with cocoa, with the rest being open forests and annuals. The local communities cultivate food crops on land they consider not suitable for cocoa. There are open spaces or grasslands mostly around Oseikojokrom and Tiafiso. Located to the North of Bia, the Yawmatwa CREMA is mostly made up of cocoa agroforests and open forests. Human settlement is however concentrated in Yawmatwa followed by Nsowakrom then Nsuatre (Figure 1). In Bokokrom, open forests are dominant with few patches of closed forests, human settlements, and annuals.
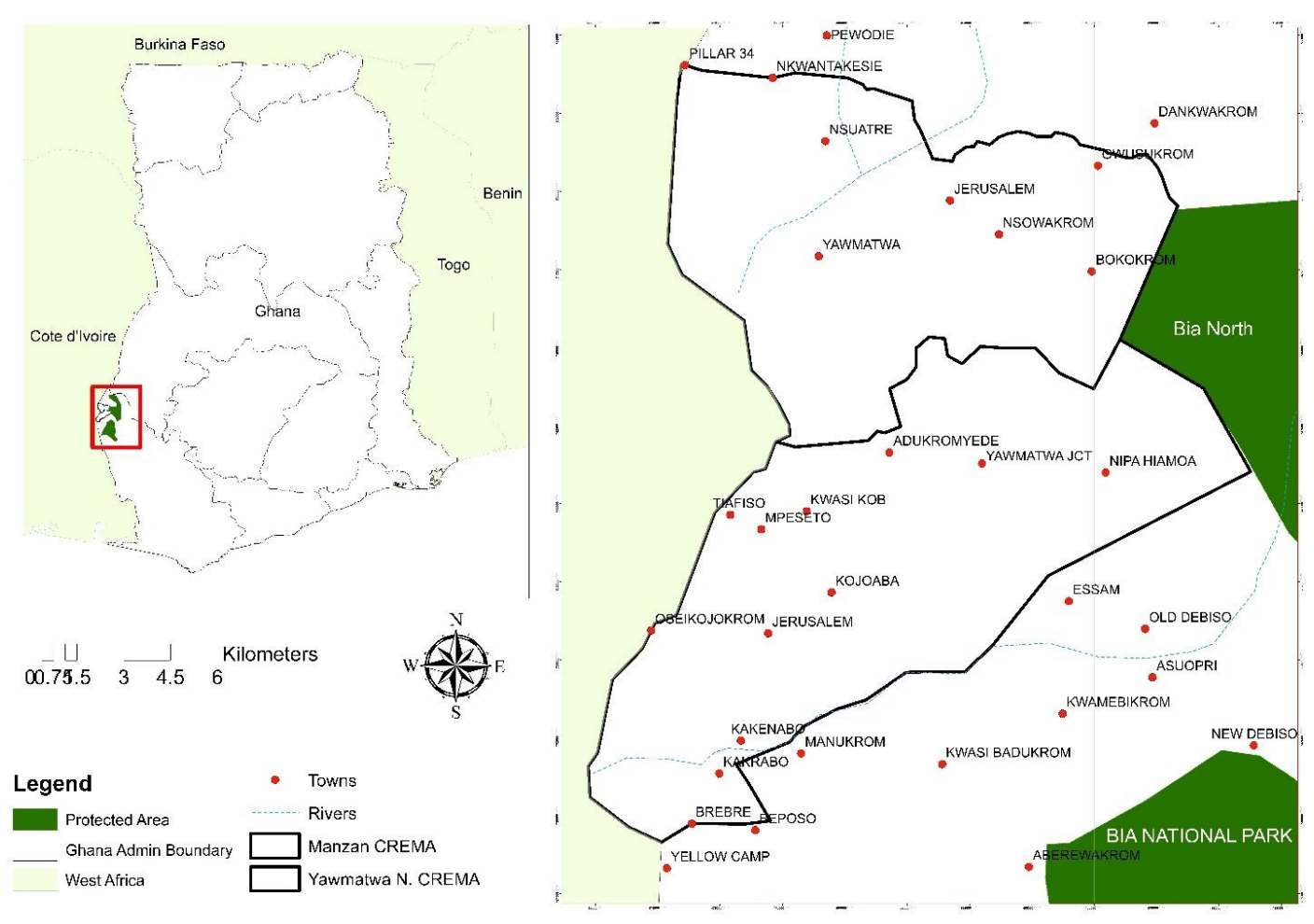

Figure 1. A map showing Ghana and the study areas 
Generally, there are no connected closed forests in both CREMAs. This lack of contiguous closed forests resulted from the traditional way of land preparation that involves clear-felling of virgin forest land usually for cocoa production. Few patches of closed forests were observed close to river banks and a few planted areas as observed around Tepakrom (Yawmatwa CREMA) and Kojoaba (Manzan CREMA). Other areas with closed canopy include sacred grooves and cemeteries that were observed in almost all the major towns in the CREMA block. The farmers in these two CREMAs practice the Shaded Cocoa Agroforestry (SCAF), a program initiated by the Netherlands Development Organization also known as the SNV. This organization helps farmers to rehabilitate their cocoa and also plant more shaded trees on their cocoa farms by supplying seeds, suckers, and small plants.

\section{Data collection}

A Rapid Biodiversity Assessment (RBA) was conducted from late September to early October (September 24, 2018, to October 8, 2018, in two proposed CREMAs (Manzan and Yawmatwa) in Sefwi-Debiso in the Bia West District, in the Western North Region of Ghana. Each proposed CREMA had three sampling sites, a total of six sampling sites: Manzan CREMA (MS1 - Manzan Site 1, MS2 - Manzan Site 2, MS3 - Manzan Site 3) and Yawmatwa CREMA (YS1 - Yawmatwa Site 1, YS2 Yawmatwa Site 2, YS3 - Yawmatwa Site 3). Sampling was carried out over a period of two weeks with an average of two days at each of the six sampling sites.

Butterflies were sampled by means of visual observations (spotting) and transect walk counts, butterfly nets, and fruit-baited Charaxes traps (Bossart and OpuniFrimpong 2009; Nganso et al. 2012; Kyerematen et al. 2014). Butterflies were identified in flight by patterns and markings on their wings, and by their mode of flight. Direct counts of individuals were done along transects of not less than $1 \mathrm{~km}$ long, making sure that individuals were counted only once and not repeated. A minimum of three hours was used for each sampling period twice each day using random walk sampling by three persons for each site under sunny conditions. All butterflies seen within $2.5 \mathrm{~m}$ on either side of the transect route and up to $5 \mathrm{~m}$ in front of the observer were recorded (Fermon et al. 2001). Aerial nets were used to catch some of the butterflies which were not easily identifiable in flight. Easily identified species were released after capture. For those that could not be captured with the aerial net, photographs were taken with a digital camera for later identification. Charaxes traps with rotten banana mixed with alcohol (beer) as bait was set up to specifically capture alcohol loving butterflies in the genus Charaxes which are fast flyers and difficult to identify in flight; as well as other butterflies attracted to fermenting fruits. Five (5) Charaxes traps were hung approximately $10-15 \mathrm{~cm}$ above the ground at equal distances of $100 \mathrm{~m}$ along each transect, starting from the edge of each sampling site to the interior of each site. A conscious effort was taken to install all traps in similar microhabitats within each sampling area. Collections were retrieved after 2 days at each sampling site. Butterflies collected from the Charaxes traps were euthanized using a killing bottle containing ethyl acetate and kept in glassine envelops for later examination and identification.

The identities of all unfamiliar butterfly species were confirmed with the help of the reference catalog on African butterflies (Larsen 2005); reference collections in the Biodiversity and Entomology Museum of the Department of Animal Biology and Conservation Science, University of Ghana; Hoskins (2015); as well as Belcastro and Larsen (2006). Butterfly species were classified into guilds: forest disturbance indicator species (FD) - (species that colonize degraded/disturbed forests), forest specialists (FS), grassland specialists (GS), and open habitat generalists (OH) (Larsen 1994, 2006).

\section{Data analysis}

Diversity indices were compared as a form of quantitative assessment of sites (Kyerematen et al. 2018). The diversity of butterfly species was measured using the Shannon-Weiner Diversity Index. Species richness was represented by the total number of species observed, and evenness of distribution of species using Pielou's Index (Magurran 2013). All analyses were performed using PRIMER 7 software and SPSS software.

\section{RESULTS AND DISCUSSION}

A total of 1352 individual butterflies belonging to 83 species from five (5) families: Nymphalidae, Papilionidae, Pieridae, Lycaenidae, and Hesperidae were recorded during the survey (Table 1), with Nymphalidae dominating in terms of numbers (663) followed by Pieridae with 582 individuals. The Family Hesperidae was the least abundant with 22 individual butterflies. Mylothris chloris, Junonia terea, Mylothris rhodope, and Mylothris poppea were the most abundant butterfly species recorded. The Nymphalids were the most diverse in terms of the number of species recorded. The Manzan CREMA was the most abundant and diverse recording 830 individual butterflies from all 83 species present; as against 522 individual butterflies from 61 species recorded in the Yawmatwa CREMA. Of the six sites sampled from both CREMAs, MS2 was the most abundant site with a total of 445 individuals, followed by YS1 and MS1 with 286 and 276 individuals respectively (Table 2).

MS2 was also the most diverse site (80 species) with a Shannon Weiner index $\left(\mathrm{H}^{1}\right)$ of 3.7424 as well as the richest among the six sampling sites with a Margalef's index (d) of 12.955; YS2 was the least diverse site with 24 species and an $\mathrm{H}^{1}$ value of 2.9757 and a total of 59 individuals (Table 2). Butterflies were generally, fairly evenly distributed in all six sites represented by a Pielou's index ranging from 0.8 to 0.92 . The second site at Yawmatwa CREMA (YS2) was the most even $\left(\mathrm{J}^{\prime}=0.936\right)$ in terms of species distribution. 
Table 1. List of butterfly species recorded during the study

\begin{tabular}{|c|c|c|c|c|c|c|c|c|c|}
\hline Family & Species & IND & MS1 & MS2 & MS2 & YS1 & YS2 & YS3 & Total \\
\hline \multirow[t]{51}{*}{ Nymphalidae } & Euphaedra harpalyce & FS & 1 & 3 & 0 & 1 & 0 & 0 & 5 \\
\hline & Euphaedra themis & FS & 1 & 2 & 0 & 0 & 0 & 0 & 3 \\
\hline & Euphaedra edwardsi & FS & 0 & 1 & 0 & 0 & 0 & 0 & 1 \\
\hline & Euphaedra sarcoptera & FS & 0 & 4 & 0 & 0 & 0 & 0 & 4 \\
\hline & Euphaedra medon & FS & 1 & 2 & 0 & 1 & 0 & 0 & 4 \\
\hline & Euphaedra crockeri & FS & 2 & 3 & 0 & 0 & 0 & 0 & 5 \\
\hline & Euphaedra eleus & FS & 2 & 1 & 0 & 2 & 0 & 0 & 5 \\
\hline & Euphaedra xypete & FS & 2 & 0 & 0 & 0 & 0 & 0 & 2 \\
\hline & Eurytela dryope & FS & 0 & 1 & 0 & 1 & 0 & 1 & 3 \\
\hline & Euriphene barombina & FS & 0 & 1 & 0 & 0 & 0 & 0 & 1 \\
\hline & Pseudacraea eurytus & FS & 1 & 2 & 0 & 1 & 2 & 1 & 7 \\
\hline & Pseudacraea lucretia & FS & 0 & 3 & 2 & 0 & 1 & 3 & 9 \\
\hline & Pseudacraea warburgi & FS & 2 & 1 & 0 & 2 & 0 & 2 & 7 \\
\hline & Pseudoneptis bugandenses & FS & 0 & 1 & 0 & 0 & 0 & 0 & 1 \\
\hline & Neptis melicerta & FS & 3 & 6 & 1 & 5 & 0 & 1 & 16 \\
\hline & Neptis metella & FS & 1 & 5 & 0 & 9 & 0 & 2 & 17 \\
\hline & Neptis morosa & GS & 2 & 4 & 1 & 6 & 0 & 1 & 14 \\
\hline & Ariadne enotrea & FS & 3 & 9 & 0 & 5 & 0 & 4 & 21 \\
\hline & Aterica galena & FS & 0 & 1 & 0 & 0 & 0 & 0 & 1 \\
\hline & Byblia anvatara & GS & 0 & 2 & 1 & 0 & 0 & 2 & 5 \\
\hline & Cymothoe egesta & FS & 0 & 1 & 0 & 0 & 0 & 1 & 2 \\
\hline & Cymothoe fumana & FS & 0 & 1 & 0 & 0 & 0 & 0 & 1 \\
\hline & Junonia terea & FD & 39 & 28 & 8 & 24 & 7 & 18 & 124 \\
\hline & Junonia oenone & $\mathrm{OH}$ & 9 & 12 & 15 & 9 & 4 & 13 & 62 \\
\hline & Hypolimnas salmacis & FS & 0 & 1 & 0 & 0 & 0 & 0 & 1 \\
\hline & Hypolimnas misippus & $\mathrm{OH}$ & 1 & 2 & 0 & 0 & 1 & 0 & 4 \\
\hline & Hypolimnas dinarcha & FS & 0 & 1 & 0 & 0 & 0 & 0 & 1 \\
\hline & Hamanumida daedalus & GS & 3 & 2 & 1 & 0 & 2 & 1 & 9 \\
\hline & Acraea consanguinea & FS & 2 & 4 & 2 & 0 & 0 & 2 & 10 \\
\hline & Acraea vestalis & FS & 5 & 9 & 1 & 3 & 1 & 0 & 19 \\
\hline & Acraea serena & $\mathrm{OH}$ & 6 & 8 & 2 & 9 & 2 & 0 & 27 \\
\hline & Kallimoides rumia & FS & 0 & 3 & 0 & 0 & 0 & 0 & 3 \\
\hline & Melanitis leda & $\mathrm{OH}$ & 1 & 2 & 0 & 0 & 0 & 0 & 3 \\
\hline & Gnophodes chelys & FS & 2 & 5 & 0 & 0 & 0 & 2 & 9 \\
\hline & Ypthimomorpha itonia & FS & 4 & 6 & 0 & 0 & 0 & 1 & 11 \\
\hline & Acraea epaea & FS & 8 & 3 & 0 & 5 & 0 & 0 & 16 \\
\hline & Acraea zetes & FS & 12 & 2 & 0 & 18 & 0 & 0 & 32 \\
\hline & Acraea egina & FS & 3 & 1 & 2 & 22 & 1 & 0 & 29 \\
\hline & Acraea encedon & $\mathrm{OH}$ & 6 & 4 & 1 & 25 & 0 & 4 & 40 \\
\hline & Acraea pseudegina & $\mathrm{OH}$ & 4 & 5 & 1 & 16 & 3 & 1 & 30 \\
\hline & Bicyclus safitza & GS & 2 & 3 & 0 & 3 & 0 & 0 & 8 \\
\hline & Bicyclus auricruda & FS & 3 & 5 & 3 & 0 & 0 & 3 & 14 \\
\hline & Bicyclus dorothea & FS & 2 & 3 & 2 & 1 & 0 & 0 & 8 \\
\hline & Ypthima condamini & GS & 0 & 2 & 1 & 0 & 0 & 1 & 4 \\
\hline & Bicyclus italus & FS & 0 & 2 & 0 & 2 & 0 & 0 & 4 \\
\hline & Bicyclus zinebi & FS & 0 & 1 & 4 & 0 & 0 & 0 & 5 \\
\hline & Bicyclus martius & FS & 1 & 2 & 0 & 1 & 0 & 1 & 5 \\
\hline & Amauris niavus & GS & 0 & 4 & 1 & 1 & 0 & 0 & 6 \\
\hline & Amauris hecate & FS & 1 & 3 & 0 & 2 & 0 & 1 & 7 \\
\hline & Amauris democles & FS & 0 & 7 & 0 & 0 & 1 & 0 & 8 \\
\hline & Danaus chrysippus & $\mathrm{OH}$ & 5 & 13 & 2 & 1 & 2 & 7 & 30 \\
\hline \multirow[t]{6}{*}{ Papilionidae } & Papilio demodocus & FD & 1 & 2 & 4 & 3 & 1 & 9 & 20 \\
\hline & Papilo dardanus & FS & 0 & 5 & 0 & 0 & 3 & 0 & 8 \\
\hline & Papilio nireus & FS & 0 & 1 & 0 & 0 & 0 & 0 & 1 \\
\hline & Papilio chrapkowskoides & FS & 0 & 1 & 0 & 0 & 0 & 0 & 1 \\
\hline & Papilio menesthius & FS & 2 & 4 & 1 & 1 & 0 & 4 & 12 \\
\hline & Graphium policenes & FS & 0 & 1 & 0 & 0 & 0 & 0 & 1 \\
\hline
\end{tabular}




\begin{tabular}{|c|c|c|c|c|c|c|c|c|c|}
\hline \multirow[t]{19}{*}{ Pieridae } & Eurema brigitta & GS & 2 & 4 & 0 & 2 & 3 & 4 & 15 \\
\hline & Eurema senegalensis & $\mathrm{OH}$ & 1 & 6 & 0 & 7 & 4 & 6 & 24 \\
\hline & Eurema hecabe & $\mathrm{OH}$ & 4 & 9 & 2 & 3 & 6 & 13 & 37 \\
\hline & Nepheronia thalassina & FS & 8 & 16 & 11 & 1 & 2 & 6 & 44 \\
\hline & Nepheronia argia & FS & 3 & 4 & 0 & 2 & 0 & 2 & 11 \\
\hline & Nepheronia pharis & FS & 1 & 5 & 0 & 0 & 3 & 4 & 13 \\
\hline & Colotis antevippe & GS & 0 & 2 & 0 & 0 & 1 & 0 & 3 \\
\hline & Colotis ione & GS & 0 & 1 & 0 & 0 & 0 & 0 & 1 \\
\hline & Belenois calypso & FS & 7 & 10 & 4 & 2 & 0 & 4 & 27 \\
\hline & Belenois gidica & GS & 2 & 0 & 0 & 0 & 0 & 1 & 3 \\
\hline & Belenois theora & FS & 1 & 2 & 1 & 0 & 0 & 1 & 5 \\
\hline & Leptosia medusa & FS & 0 & 2 & 0 & 0 & 0 & 0 & 2 \\
\hline & Leptosia alcesta & FS & 0 & 6 & 0 & 0 & 0 & 0 & 6 \\
\hline & Catopsilia florella & $\mathrm{OH}$ & 23 & 16 & 9 & 18 & 0 & 13 & 79 \\
\hline & Mylothris rhodope & FS & 11 & 33 & 7 & 29 & 5 & 8 & 93 \\
\hline & Mylothris poppea & FS & 14 & 34 & 9 & 18 & 0 & 10 & 85 \\
\hline & Mylothris chloris & $\mathrm{OH}$ & 43 & 59 & 6 & 11 & 0 & 6 & 125 \\
\hline & Appias Sylvia & FS & 1 & 3 & 0 & 0 & 1 & 0 & 5 \\
\hline & Appias phaola & FS & 0 & 2 & 0 & 1 & 0 & 1 & 4 \\
\hline \multirow[t]{3}{*}{ Hesperiidae } & Pyrrhiades lucagus & FS & 3 & 2 & 0 & 1 & 0 & 1 & 7 \\
\hline & Coeliades forestan & $\mathrm{OH}$ & 0 & 3 & 0 & 0 & 0 & 0 & 3 \\
\hline & Tagiades flesus & FS & 0 & 7 & 0 & 5 & 0 & 0 & 12 \\
\hline \multirow[t]{4}{*}{ Lycaenidae } & Tuxentius carana & FS & 1 & 0 & 0 & 0 & 0 & 0 & 1 \\
\hline & Euchrysops albistriata & GS & 2 & 4 & 2 & 4 & 0 & 2 & 14 \\
\hline & Hypolycaena liara & FS & 4 & 3 & 0 & 3 & 2 & 7 & 19 \\
\hline & Hypolycaena hatita & FS & 2 & 1 & 2 & 0 & 1 & 2 & 8 \\
\hline Total & & & 276 & 445 & 109 & 286 & 59 & 177 & 1,352 \\
\hline
\end{tabular}

Manzan Sites (MS1: Manzan Site 1, MS2: Manzan Site 2, MS3: Manzan Site 3), Yawmatwa Sites (YS1: Yawmatwa Site 1, YS2: Yawmatwa Site 2, YS3: Yawmatwa Site 3). IND - Indicator Species

Key indicator species of severe disturbance in the forest zone (Larsen 1994, 2006) recorded during the survey included Catopsilia florella, Eurema hecabe, Belenois creona, Danaus chrysippus, Hamanumida daedalus, Hypolimnas misippus, and Acraea pseudegina (Figure 2). Papilio demodocus, Junonia oenone, Mylothris chloris, Junonia terea (Figure 3.A-D).

Butterfly assemblage in an area is determined by vegetation cover and diversity of the vegetation present (Addo-Fordjour et al. 2015; Kyerematen et al. 2018; Serrat et al. 2015; Ubach et al. 2020). The ongoing initiative by the Netherlands Development Organization (SNV), to practice the Shaded Cocoa Agroforestry (SCAF), has provided vegetation cover and protected the habitats of species in these areas which probably has accounted for the high diversity of butterfly species here. Agroforestry has also accounted for habitat transformation according to a study conducted in Eastern Himalaya in India (Sharma et al. 2020). Though the two CREMAs were not being compared in this study, observation from the sampling indicated that there were more butterflies in the Manzan CREMA than the Yawmatwa CREMA due probably to larger portions of the forest at the Yawmatwa CREMA having been converted to farmlands and human settlements. This observation is in agreement with a study by Kyerematen et al. (2014) where portions of the Ramsar site at Muni-Pomadze in the Central Region of Ghana which had been converted to farmlands, recorded a lower abundance and diversity than the undisturbed part of the
Ramsar site during the same sampling period. The higher the environmental stressors (environmental disturbances such as conversion of forests to farmlands and settlements), the lower the assemblage of butterflies in an area (Kyerematen et al. 2018). Even though the Manzan CREMA also had portions converted to farmlands (mainly cocoa and plantain), there were still large portions of intact forests. Factors such as larval host plants, resource availability for adults, behavioral traits, and interaction with other species may have accounted for the increase in butterfly diversity and richness in MS2 and the Manzan CREMA as a whole. Most of the indicator species of the forest category were recorded from the forest compartment in the Manzan CREMA. Figure 2. shows a list and the percentage abundance of some key indicator species of severe disturbance in the forest zone (Larsen 1994, 2006) recorded during the survey.

Table 2. Diversity indices of sites in the CREMAs

\begin{tabular}{lccccc}
\hline & S & N & d & J' & H' \\
\hline MS1 & 54 & 276 & 9.4299 & 0.8288 & 3.3059 \\
MS2 & 80 & 445 & 12.955 & 0.8540 & 3.7424 \\
MS3 & 31 & 109 & 6.3948 & 0.8854 & 3.0403 \\
YS1 & 43 & 286 & 7.4258 & 0.8560 & 3.2195 \\
YS2 & 24 & 59 & 5.6407 & 0.9363 & 2.9757 \\
YS3 & 43 & 177 & 8.1141 & 0.8926 & 3.3573 \\
\hline
\end{tabular}

Note: S: number of species, N: number of individuals, D: Margalef's Index, $\mathrm{J}^{1}$ : Pielou's index, $\mathrm{H}^{1}$ : Shannon-Weiner diversity index 


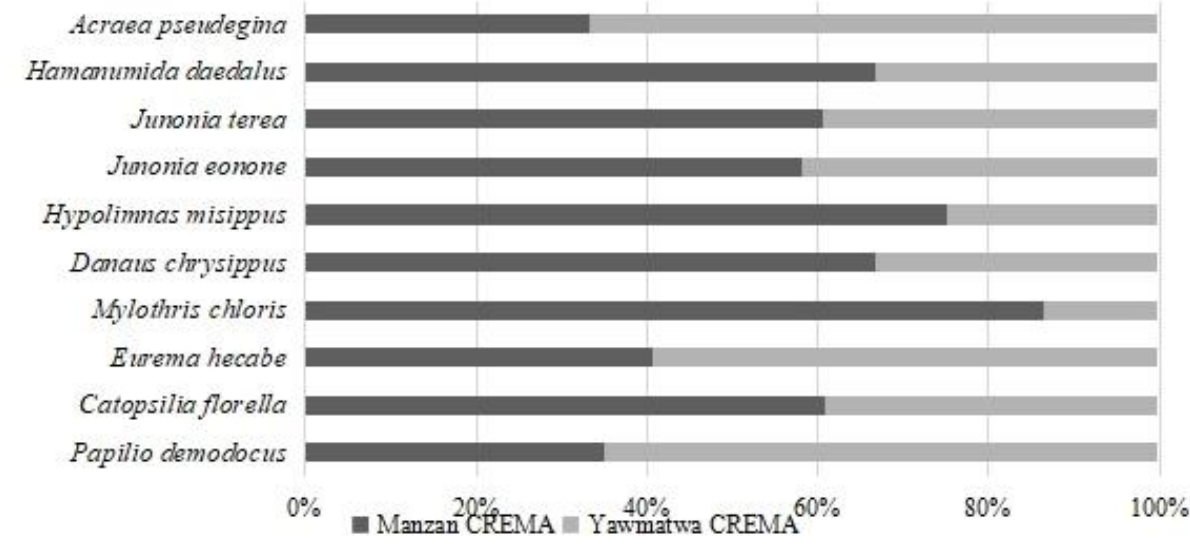

Figure 2. Percentage Abundance of Indicator Species of Severe Forest Disturbance (Larsen 1994, 2006) Recorded in the CREMAs

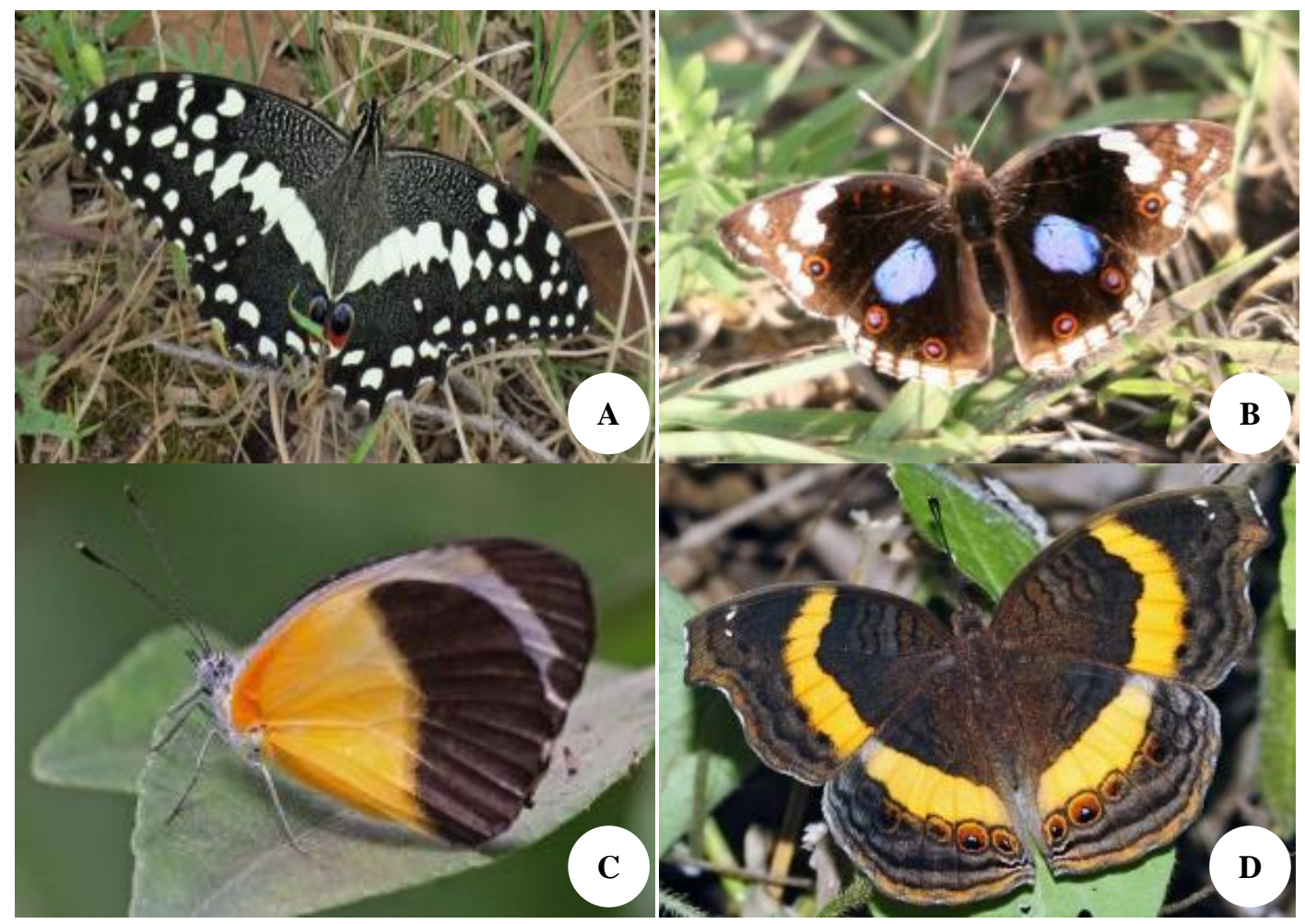

Figure 3. Some butterflies of conservation importance reported in the two CREMAs. A. Papilio demodocus, B. Junonia oenone, C. Mylothris chloris, D. Junonia terea

The family Nymphalidae is the most diverse and abundant butterfly family common in forested areas, accounting for the highest number of species and individuals recorded in this study. The Pieridae are a large family of butterflies found mainly in the tropical regions of Africa and Asia, and many are open habitat generalists (Larsen 2006). The Pierids were recorded in high numbers in open habitats where forests had been converted to farmlands and human settlements. The family Hesperidae also known as the
Skippers, exhibits a rapid, erratic ("skipping") flight pattern. Only three species and a total of twenty-two (22) individuals were recorded in this study; making this family the least diverse, as well as the least abundant group of butterflies recorded in the study.

We discuss here, some indicator species of conservation concern (Larsen 1994, 2006) recorded in this study because our aim is to assess these two CREMAs to ascertain whether there is a need for conservation intervention. 
About $90 \%$ of these indicator species were recorded in the open areas and along the edges of the cocoa farms. Junonia terea is an indicator species of severe disturbances in forest areas (Larsen 1994, 2006; Kyerematen et al. 2018). MS1 had the highest number of individuals recorded for this species, indicating that MS1 was the most highly disturbed corroborated by the many anthropogenic activities observed in this particular site, with farming being the most dominant. Mylothris chloris is usually found in open woodland, forest clearings, savanna, parks and gardens (Belcastro and Larsen 2006) and so it is not strange that the survey recorded 125 individuals in all, an indication of the negative impact of anthropogenic activity within these two forest areas.

Catopsilia florella (an open country species) which belongs to the family Pieridae was recorded in relatively large numbers in open areas and clearings in the forest. It is also known as the African migrant, African emigrant, or common vagrant, and is widespread in Africa (including Madagascar) and the Canary Islands. It exhibits sexual dimorphism and is a strong flier, occasionally migrating in large numbers (Larsen 2005).

The presence of Papilio demodocus, Eurema hecabe, Eurema brigitta and Danaus chysippus is a clear indication of some disturbance in both CREMAs resulting from forest degradation (Larsen 1994). Theoretically, these species are known to be generally common with fairly wide ranges and can colonize both intact and disturbed forests (Magurran 2013). Six individuals of Hamanumida daedalus were also recorded in both CREMAs. This species is a grassland or savanna species, sometimes found in the transition zones to the savanna regions. It is usually associated with dry, rocky grasslands where there are scattered bushes and trees, but also rapidly colonizes abandoned agricultural lands (Larsen 2006). Finding this species in a forested area such as the study area, area from its natural habitat raises a lot of concern.

Some indicator species in the forest specialists category (Larsen 1994, 2006) such as Euphaedra spp (9 different species recorded), Hypolimnas salmacis, Hypolimnas dinarcha, Euriphene barombina, Aterica galene, Melanitis leda, Gnophodes chelys, Cymothoe egesta, Papilio menesthius, Nepheronia thalassina, Cymothoe fumana and Kallimoides rumia were however also recorded despite the observed farming activities. Though, not in high numbers, the result was impressive in terms of diversity. This is an indication of the general health of the forested portions of these CREMAs. From a study conducted by Kyerematen et al. (2018) within the Tarkwa Goldmines, it is possible to record indicator species of degraded forests and still have records of deep forested species within a degraded area. Even though, the Charaxes trap captured some butterflies attracted to the fermenting fruit, it was however surprising that butterflies belonging to the genus Charaxes which are also good forest indicators were neither captured nor spotted even though the forest compartment of MS2 would have been a preferred habitat for this group of butterflies. This is probably a sign that anthropogenic activities are negatively impacting these proposed CREMAs, and therefore the need for conservation interventions.
This study is the first to be conducted in these two proposed CREMAs and has provided baseline data on butterfly species for these CREMAs. Species were generally evenly distributed across the entire study area. The 1352 butterflies belonging to 83 species from 38 genera, and five families recorded over the two week sampling period, is an indication of the richness of biodiversity here. Even though the butterfly diversity was high, the presence and abundance of 10 species belonging to the forest disturbance indicator category, accounting for $38.5 \%$ of the total number of individuals recorded, was an indication that some areas within the concession were degraded. Papilio demodocus, Mylothris chloris, Junonia oenone, and Junonia terea which were recorded in high numbers, are some of the most conspicuous species when it comes to indicators of severe forest disturbances (Larsen 1994). Some forested areas within the two CREMAs are in good condition despite the abundance of species that indicate slight to severe forest disturbance. The two CREMAs are important and show high diversity and is suitable for conservation measures. We, therefore, recommend that conservation measures be put in place to minimize anthropogenic activities; primarily farming and human settlements which could negatively impact butterfly assemblage as well as composition. Other conservation measures that need to be put in place include sustainable agricultural practices (to promote soil and biodiversity conservation), avoiding the use of pesticides, as well as avoidance of legal and illegal mining. It is also suggested that additional or alternative livelihoods be provided for the locals to avoid activities that cause destruction to habitats and loss of biodiversity. Patches of forests within the CREMAs must also be protected to serve as refuges for butterflies whose habitats are destroyed.

\section{ACKNOWLEDGEMENTS}

The authors are grateful to the Netherlands Development Organization (SNV) for sponsoring this Rapid Biodiversity Assessment.

\section{REFERENCES}

Addo-Fordjour P, Osei BA, Kpontsu EA. 2015. Butterfly community assemblages in relation to human disturbance in a tropical upland forest in Ghana, and implications for conservation. J Insect Biodiv 3 (6): 1-18.

Bakowski M, Doku-Marfo E. 2009. A rapid survey of butterflies in Ajenjua Bepo and Mamang River Forest Reserves, Eastern Ghana. Chapter Three In A Rapid Biodiversity Assessment of the Ajenjua Bepo and Mamang River Forest Reserves, Ghana. RAP Bulletin of Biological Assessment. Conservation International. Washington DC.

Belcastro C, Larsen TB. 2006. Butterflies as an indicator group for the conservation value of the Gola forests in Sierra Leone. Report to the Gola Forest Conservation Concession Project. Global Forest and Climate Change Programme (GFCCP), IUCN, Gland.

Bossart JL, Opuni-Frimpong E. 2009. Distance from edge determines fruit-feeding butterfly community diversity in Afrotropical forest fragments. Environ Entomol 38 (1): 43-52.

Forestry Commission of Ghana 2010. Bia National Park \& Resource Reserve/Biosphere http://www.fcghana.com/eco_tourism/bia.htm 
Hinneh S. 2017. Ghana's CREMA-The Building Block to Natural Resource Management in Africa. Modern Ghana News. https://www.modernghana.com/news/763697/ghanas-crema-thebuilding-block-to-natural-resour.html

Hoskins A. 2015. Butterflies of the World. New Holland Publishers, Nederland.

Kyerematen R, Adu-Acheampong S, Acquah-Lamptey D, Sigismund RA, Owusu EH, Mantey J. 2018. Butterfly diversity: An indicator for environmental health within the Tarkwa Gold mine, Ghana. Environ Nat Resour Res 8 (3): 69-83.

Kyerematen, R., Acquah-Lamptey D, Owusu EH, RS Anderson, NtiamoaBaidu Y. 2014. Insect Diversity of the Muni-Pomadze Ramsar Site: An important site for biodiversity conservation in Ghana. J Insects 2014 (985684): 1-11.

Larsen TB. 1994. The Butterflies of Ghana - Their Implications for Conservation and Sustainable Use. Report to IUCN54 and Dept. of Game \& Wildlife, Ghana.

Larsen, TB. 2005. Butterflies of West Africa. Vol. 2. Apollo Books, Stenstrup, Denmark.

Larsen, TB. 2006. The Ghana Butterfly Fauna and its Contribution to the Objectives of the Protected Areas. GWSP and IUCN Report 63.

Magurran AE. 2013. Measuring Biological Diversity. Wiley \& Sons Science, New York.

Nganso BT, Kyerematen R, Obeng-Ofori D. 2012. Diversity and Abundance of Butterfly Species in the Abiriw and Odumante Sacred Groves in the Eastern Region of Ghana. Res Zool 2 (5): 38-46.
Orimaye JO, Odunayo OO, Okosodo EF, Ojo VA, Agbelusi TO. 2016. Butterfly species diversity in protected and unprotected habitat of Ise Forest Reserve, Ise Ekiti, Ekiti State. Adv Ecol 2016: 7801930. DOI: $10.1155 / 2016 / 7801930$

Pearson DL, Cassola F. 1992. World-wide species richness patterns of tiger beetles (Coleoptera: Cicindelidae): indicator taxon for biodiversity and conservation studies. Conserv Biol 6 (3): 376-391.

Serrat A, Pons P, Puig-Gironès R, Stefanescu C. 2015. Environmental factors influencing butterfly abundance after a severe wildfire in Mediterranean vegetation. Anim Biodiv Conserv 38 (2): 207-220.

Sharma, K., Acharya, B.K., Sharma, G., Valente, D., Pasimeni, M.R., Petrosillo, I. and Selvan, T.. 2020. Land use effect on butterfly alpha and beta diversity in the Eastern Himalaya, India. Ecol Indicat 110: 105605. DOI: 10.1016/j.ecolind.2019.105605

Ubach A, Páramo F, Gutiérrez C, Stefanescu C. 2020. Vegetation encroachment drives changes in the composition of butterfly assemblages and species loss in Mediterranean ecosystems. Insect Conserv Divers 13 (2): 151-161.

Zakaria M, Rajpar MN, Ozdemir I, Rosli Z. 2016. Fauna diversity in tropical rainforest: threats from land-use change of tropical forests. In: Blanco JA, Chang SC, Lo YH (eds.). The Challenges of Maintaining Ecosystem Services while Managing the Landscape. IntechOpen, UK. DOI: $10.5772 / 64963$ 